\title{
Screening for CLCN5 mutation in renal calcium stone formers patients
}

\author{
MARIA ALICE P. REBELO ${ }^{1}$, VERA TOSTES ${ }^{2}$, NORDEVAL C. ARAÚJO ${ }^{1}$ \\ SABRINA V. MARTINI ${ }^{2}$, BRUNO F. BOTELHO ${ }^{2}$, WILLIAM B. GUGGINO ${ }^{3}$ \\ and MARCELO M. MORALES ${ }^{2}$ \\ ${ }^{1}$ Discipline of Nephrology, Faculdade de Ciências Médicas, Hospital Universitário Pedro Ernesto \\ Universidade Estadual do Rio de Janeiro (UERJ), Av. 28 de Setembro, 77 \\ 20551-030 Rio de Janeiro, RJ, Brasil \\ ${ }^{2}$ Instituto de Biofísica Carlos Chagas Filho, Universidade do Federal do Rio de Janeiro (UFRJ) \\ 21949-900 Rio de Janeiro, RJ, Brasil \\ ${ }^{3}$ Department of Physiology of the Johns Hopkins University School of Medicine \\ 725 N Wolfe ST, Baltimore, Maryland, 21205 USA
}

Manuscript received on March 30, 2004; accepted for publication on July 30, 2004; presented by Lucia Mendonça Previato

\begin{abstract}
Thirty-five patients (23 males and 12 females), age $35 \pm 13$ years old, presenting either idiopathic calcium nephrolithiasis, nephrocalcinosis or mild renal failure with idiopathic calcium nephrolithiasis were selected for the analysis of low molecular weight proteinuria and the possible mutations occurrence in the chloride channel gene CLCN5. The urinary ratio of $\beta 2$-microglobulin and creatinine $(\beta 2 \mathrm{M} / \mathrm{Cr})$ was very high in a transplanted woman with nephrocalcinosis $(>3.23 \mathrm{mg} / \mathrm{mmol})$ and slightly high in five patients $(>0.052$ or $<1.0 \mathrm{mg} / \mathrm{mmol}$ ) with multiple urological manipulations. Other studied patients showed $\beta 2 \mathrm{M} / \mathrm{Cr}$ ratio at normal range $(0.003-0.052 \mathrm{mg} / \mathrm{mmol})$ without gender difference $(\mathrm{p}>0.05)$. Mutation analysis of CLCN5 gene was performed in 26 patients of 35 selected (11 with idiopathic hypercalciuria; 6 men with normal calciuria; 3 with mild renal insufficiency and 6 with nephrocalcinosis) and was normal in all subjects even in those with abnormal molecular weight proteinuria. Conclusion: CLCN5 gene mutation is not a common cause of kidney stone disease or nephrocalcinosis in a group of Brazilian patients studied.
\end{abstract}

Key words: nephrolithiasis, nephrocalcinosis, low-molecular-weight proteinuria, CLCN5 mutation.

\section{INTRODUCTION}

The genetic background of the idiopathic calcium nephrolithiasis is unknown. Some advances have been made in the understanding of disorders that can exhibit nephrolithiasis as a symptom such as primary hyperoxaluria (Danpure et al. 1993), cystinuria (Stoller et al. 1999) and Dent's disease (Xlinked hypercalciuria and nephrolithiasis) (Schein-

Correspondence to: Marcelo Marcos Morales, MD, Ph.D.

E-mail: mmorales@biof.ufrj.br man et al. 1993), giving some insight into the ethiopathogenesis of calcium idiopathic nephrolithiasis. Dent's disease, for example, is a rare form of renal tubular disorder and it is characterized by hypercalciuria and low molecular-weight proteinuria besides all features of idiopathic nephrolithiasis, such as calcium stone formation and occasionally nephrocalcinosis and renal failure (Scheinman et al. 1993, Frymoyer et al. 1991, Wrong et al. 1994, Igarashi et al. 1995, Hoopes et al. 1998). The discovery of a 
hypercalciuric man, apparently idiopathic, that was in fact a true case of asymptomatic Dent's disease (Scheinman et al. 1993), has excited a stone investigators group to look for CLCN5 (gene that encodes for $\mathrm{ClC}-5$ chloride channel) gene mutations. Mutation in CLCN5 is the pathophysiological basis for Dent's disease that can also present calcium stone formation with idiopathic hypercalciuria, nephrocalcinosis and renal insufficiency. Scheinman et al. in a study that screened 101 patients for low molecular weight proteinuria (LMWP) and presenting idiopathic hypercalciuric found only slight abnormalities in the LMWP in nine patients, none of them had a mutation in CLCN5 (Scheinman et al. 2000). Although the LMWP ( $\beta 2$-microglobuline or retinolbinding protein) study still a useful tool for screening genetic involvement in these patients that usually are male. The same procedure can also be used for the screening of genetic defect carrier female (Scheinman et al. 2000).

In idiopathic lithiasis, which is the main etiologic diagnosis of the renal stone formers, the hypercalciuria is the major urinary risk factor identified. The cellular mechanism of this metabolic disorder is unclear. Nephrocalcinosis is found during imaging studies of renal stone patients and in such occasion idiopathic hypercalciuria, hyperparathyroidism and distal acidification defect must be investigated.

Among all factors involved in the lithogenesis, the present study aims to search for a CLCN5 gene mutation in the context of renal idiopathic calcium lithiasis and/or nephrocalcinosis patients.

\section{MATERIALS AND METHODS}

\section{PATIENTS}

Recurrent calcium stone formers and/or patients with nephrocalcinosis from Outpatient Clinic of Pedro Ernesto Hospital, Rio de Janeiro, underwent a routine etiologic and metabolic investigation as previously described (Rebelo et al. 1996). Thirtyfive patients (23 males), age $35 \pm 13$ (SD) years old, with idiopathic calcium nephrolithiasis, nephrocalcinosis or mild renal failure with idiopathic cal- cium nephrolithiasis were selected. The procedure, briefly, comprised clinical history and physical examination; revision of previously abdominal roentgenogram and renal ultrasound performed; chemical composition analysis of stone (if available); urine spot sample for urinalysis and qualitative cystine investigation; urine culture; a 24-hour urine collection and fasting venous blood sampling to determine creatinine clearance, proteinuria, calcium, phosphate, uric acid, eletrolytes, urine citrate and oxalate, peripheral blood cell count and serum parathyrode hormone (iPTH). Hyperparathiroidism or other hypercalcemic disorders, complete distal renal form of tubular acidosis and anatomic abnormality were excluded of tests for distal acidification ability used in order to detect the incomplete form of distal renal tubular acidosis (iRTA). The test consisted of urinary $\mathrm{pH}$ measurement after 12-hours water deprivation. If the $\mathrm{pH}$ was less than 5.5 the distal acidification was interpreted as normal; otherwise, the test is complemented by oral furosemide (Lasix ${ }^{\circledR}, 40 \mathrm{mg}$ ). In this case, the urinary $\mathrm{pH}$ is measured hourly, up to 4-hour post-ingestion; if urine $\mathrm{pH}$ was less than 5.5, at any time, the acidification was interpreted as normal; otherwise, a short ammonium chloride loading test is made (the patient is challenged with an acute acid load as ammonium chloride, $0.1 \mathrm{~g} / \mathrm{kg}$ body weight, ingested during 45 minutes to 1-hour, and urine $\mathrm{pH}$ has measured hourly during 8 hours following drug ingestion). The averages of the 6 last samples were used to interpret the test. The ability to acidification is normal if the attained $\mathrm{pH}$ is 5.3 or less. If patient fail to lower the $\mathrm{pH}$ to 5.3 or less, i. e. $\mathrm{pH}>5.3$, the diagnosis of incomplete form of distal renal tubular acidosis is considered.

\section{Analytical Methods}

Blood and urine biochemical parameters were determined by standard techniques previously used (Rebelo et al. 1996). Immunoreactive parathyroid hormone in serum (iPTH, intact molecule) was assayed by radioimmunoassay (Immunolite kits, Diagnostic Products, Los Angeles, CA, USA). Uri- 
nary citrate was measured enzymatically with citrate liase (Sigma-Aldrich Corporation, St. Louis, MO, USA) and oxalate by enzymatic-colorimetric assay (Sigma-Aldrich Corporation, St. Louis, MO, USA). Urine $\mathrm{pH}$ was measured using a $\mathrm{pH}$ meter (Metronic, Minneapolis, MN, USA). The term idiopathic hypercalciuria is applied to hypercalciuria with normocalcemia in the absence of other mineral disorders known to cause hypercalciuria.

\section{$\beta 2$-MICROGLOBULIN $(\beta 2 \mathrm{M})$}

The subjects collected $250 \mathrm{ml}$ of the first morning urine in sodium azide, $200 \mathrm{mg} / \mathrm{l}$ final concentration, sent to the laboratory at room temperature. The $\mathrm{pH}$ was measured immediately and, if necessary, adjusted to $\mathrm{pH}>5.5$ with alkali. $\beta 2 \mathrm{M}$ was measured by fluorimmunoassay (Vidas $\beta 2$-microglobulina; bioMérieux, MO, USA) within four hours of collection. Creatinine and total proteinuria were also evaluated in the same sample.

The $\beta 2 \mathrm{M}$ results were expressed in relation to the creatinine in the same sample $(\beta 2 \mathrm{M} / \mathrm{Cr}$ ratio; $\mathrm{mg} / \mathrm{mmol}$ ) and as concentration $(\mathrm{mg} / \mathrm{l})$. Normal $\beta 2 \mathrm{M} / \mathrm{Cr}$ ratio is less than $0.052 \mathrm{mg} / \mathrm{mmol}$ (Scheinman et al. 2000).

The reference concentration $(\mathrm{mg} / \mathrm{l})$ ranges are: from 20 to 39 years old: mean 0.01 and upper limit 0.74; from 40 to 59 years-old: mean: 0.05 and upper limit 1.2.

\section{Mutation Analysis of the ClCN5 Gene}

In 26 patients leukocyte DNA was extracted (Miller et al. 1998) and used with CLCN5 specific primers for polymerase chain reaction (PCR) amplification utilizing the conditions described in Table I. The PCR products were purified (QIAquick PCR purification kit; Qiagen, Valencia, CA, USA) and DNA sequence of the PCR products was determined by the use of Taq polymerase cycle sequencing and a semi-automated detection system (Perkin-Elmer, Applied Biosystem, Foster City, CA, USA). The primers were designed based in the CLCN5 gene (genebank accession number 15309448).

\section{RESULTS}

The urinary $\beta 2$-microglobulin $(\beta 2 \mathrm{M})$ was evaluated in 35 subjects ( 23 male) of whom 25 presented idiopathic calcium stone disease ( 3 with mild renal insufficiency), 6 presented nephrocalcinosis and 4 were asymptomatic offspring of stone and nephrocalcinosis patients. The mean and median of results are shown in Table II. The urine $\mathrm{pH}$ varied from 5.53 to 7.60 (median 6.20). The results of $\beta 2 \mathrm{M}$ expressed as a creatinine ratio, disclosed six patients as having abnormal low molecular weight proteinuria: the transplanted one and 5 cases with multiple urological manipulations for relief of stone obstructions; the total proteinuria was slightly increased, i.e., less than $700 \mathrm{mg}$ protein/g creatinine. Overall, not including the transplanted patient, $\beta 2 \mathrm{M}$ represented less than $20 \%$ of total proteinuria (3\% to $16 \%$ ). In the transplanted patient the $\beta 2 \mathrm{M}$ corresponded to more than $73 \%$ of total protein excretion. (Table II).

The normal $\beta 2 \mathrm{M} / \mathrm{Cr}$ ratio $(\mathrm{mg} / \mathrm{mmol})$ ranged from 0.003 to 0.052 ; median: 0.012 ; men: from 0.003 to 0.052 ; median: 0.010 , and women: from 0.006 to 0.028 ; median 0.0125 ; There was no gender difference, Zcalc $=-1.08 ; \mathrm{p}=0.28$; MannWhitney test.

\section{DNA Analyses for ClCN5 Mutations}

The CLCN5 gene was analyzed in 26 subjects: 11 with idiopathic hypercalciuria; 6 idiopathic calcium lithiasis men with normal calciuria; 5 calcium stone disease and light to moderate renal insufficiency degrees, 6 nephrocalcinosis ( 3 without renal stone). Family history of renal stone disease could be obtained in 23 cases and it was positive in about $70 \%$. Some features of these patients are in Table III.

Direct DNA sequencing of the CLCN5 gene did not show any mutation even in those cases with low molecular weight proteinuria.

\section{DISCUSSION}

The renal stone is a clinical symptom which has high prevalence (affecting 1 to $12 \%$ of the population), significant recurrence rates and high mor- 
TABLE I

Polymerase Chain Reaction (PCR) amplication conditions and primers sequences. The temperature, time of each PCR step, number of PCR cycle, and primers used to amplify the different exons of CLCN5 are shown. Denaturation (Denat); Annealing (Anneal); Extension (Ext.).

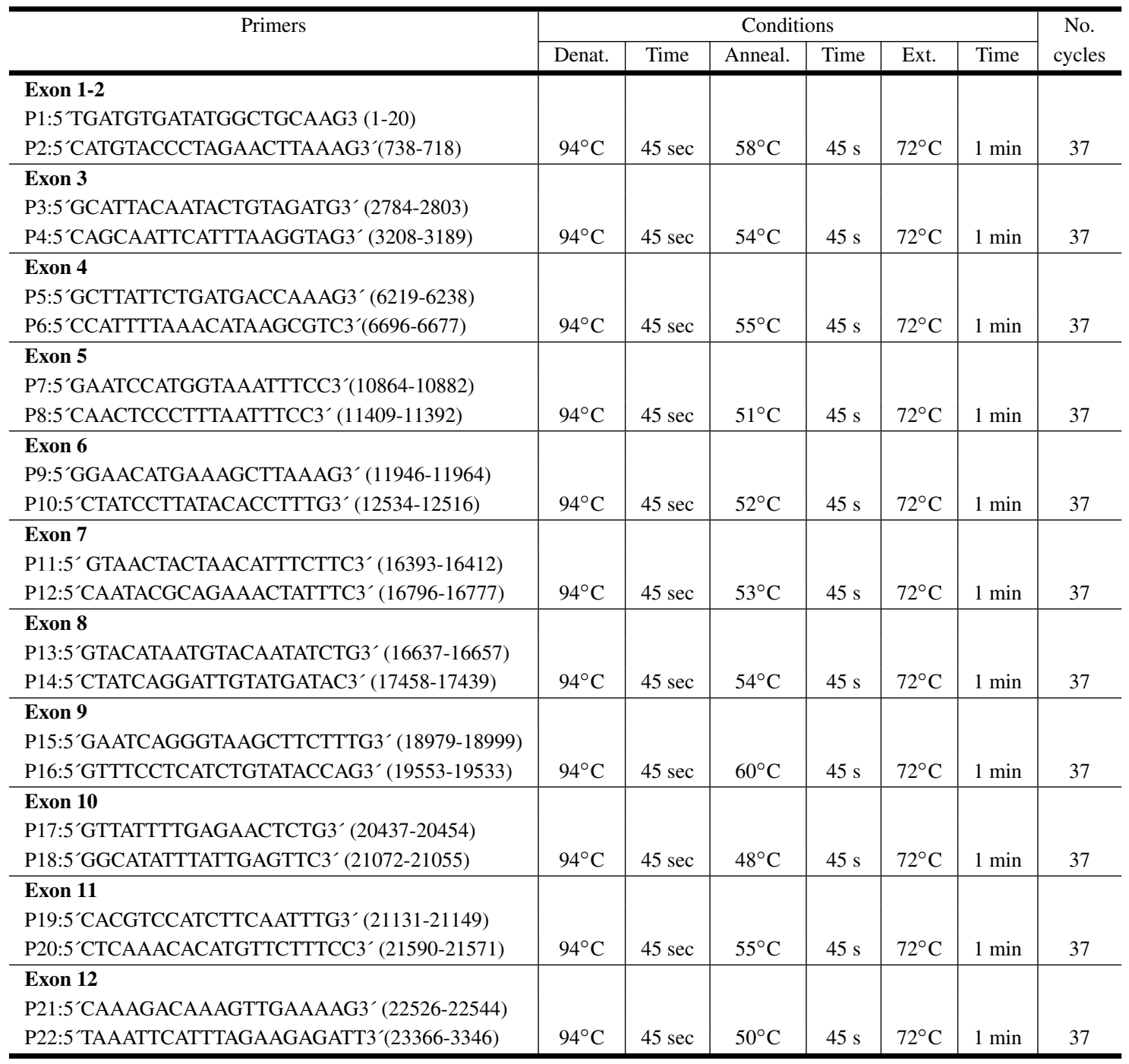

bidity and often requires hospitalization for relief of renal spasmatic crisis or to treat unusual complications, such as acute urinary obstruction, infection or urinary sepsis.

In idiopathic calcium stone disease, the high frequency of nephrolithiasis familial history, as in this casuistic, suggest a genetic base. Although there are many possibilities of altered gene to ac- count for idiopathic hypercalciuria (vitamin D receptor gene, sodium-phosphate co-transporter gene, human homologous with the rat soluble adenylate cyclase gene, renal chloride channel gene and others), so far none has been found to be prevalent (Scheinman et al. 2000, Reed et al. 2002).

In this study, patient selection was based on the presence of either idiopathic calcium nephrolithia- 
TABLE II

Results of $\beta 2$-microglobulin $(\beta 2 \mathrm{M})$, total protein and $\mathbf{p H}$ In the first urine in the morning; $\mathbf{n}=35(23 \mathrm{M} / \mathbf{1 2 F})$.

\begin{tabular}{l|c|c|c|c|c|c}
\hline & $\begin{array}{c}\text { Age } \\
(\text { years })\end{array}$ & $\begin{array}{c}\beta 2 \mathrm{M} \\
(\mathrm{mg} / \mathrm{l})\end{array}$ & $\begin{array}{c}\beta 2 \mathrm{M} / \mathrm{Cr} \\
(\mathrm{mg} / \mathrm{mmol})\end{array}$ & $\begin{array}{c}\beta 2 \mathrm{M} / \mathrm{Pr} \\
(\%)\end{array}$ & $\begin{array}{c}\beta 2 \mathrm{M} \\
\mathrm{mg} / \mathrm{g} \mathrm{Cr}\end{array}$ & $\mathrm{pH}$ \\
\hline Median & 35,00 & 0,08 & 0,01 & 1,20 & 101,00 & 6,20 \\
\hline Mean & 35,20 & 0,28 & 0,15 & 4,36 & 197,38 & 6,30 \\
\hline Standard deviation & 13,30 & 0,70 & 0,56 & 12,94 & 187,71 & 0,49 \\
\hline
\end{tabular}

TABLE III

Casuistic, ethiologic diagnoses and urinary metabolic abnormalities in selected patients for CLCN5 mutation analyses.

\begin{tabular}{l|c|c|c|c|c|c|c|c}
\hline & Gender & $\begin{array}{c}\text { Familial } \\
\text { Antecedent }\end{array}$ & $\begin{array}{c}\text { IPTH* }^{*} \\
(\mathrm{pg} / \mathrm{ml})\end{array}$ & $\begin{array}{c}\text { Hypo- } \\
\text { citraturia }\end{array}$ & $\begin{array}{c}\text { Hyper- } \\
\text { calciuria }\end{array}$ & $\begin{array}{c}\text { Hyper- } \\
\text { uricosuria }\end{array}$ & $\begin{array}{c}\text { Hyper- } \\
\text { phosphaturia }\end{array}$ & $\begin{array}{c}\text { Hyper- } \\
\text { oxaluria }\end{array}$ \\
\hline $\begin{array}{l}\text { Idiopathic } \\
\text { hypercalciuric } \\
(\mathrm{n}=11)^{1}\end{array}$ & $7 \mathrm{M} / 4 \mathrm{~F}$ & $8 / 10$ & 33 & $9 / 11$ & $11 / 11$ & $5 / 11$ & $3 / 9$ & $1 / 11$ \\
\hline $\begin{array}{l}\text { Idiophatic calcium } \\
\text { nephrolithiasis, } \\
\begin{array}{l}\text { normal renal } \\
\text { funcion (n=6) }\end{array}\end{array}$ & $6 \mathrm{M}$ & $3 / 4$ & 29 & $3 / 6$ & $0 / 6$ & $0 / 6$ & $1 / 3$ & $0 / 5$ \\
\hline $\begin{array}{l}\text { Idiophatic calcium } \\
\text { nephrolithiasis and } \\
\text { renal falure (n=6) }\end{array}$ & $3 \mathrm{M}$ & $2 / 3$ & 36 & $2 / 3$ & $1 / 3$ & $3 / 3$ & & \\
\hline $\begin{array}{l}\text { Nephrocalcinosis } \\
(\mathrm{n}=6)^{2}\end{array}$ & $2 \mathrm{M} / 4 \mathrm{~F}$ & $3 / 6$ & 20 & $4 / 5$ & $1 / 4$ & $2 / 5$ & $0 / 4$ & $1 / 2$ \\
\hline
\end{tabular}

$(\mathrm{X} / \mathrm{Y})=$ positive/analised; $(*)$ median; (1) one patient had iRTA; (2) including two mild renal failure, two had stones, one had tubular ectasia; intact parathormone (iPTH); Male (M), Female (F).

sis (with or without renal insufficiency) or image of nephrocalcinosis, in order to increase the odds of the group to represent CLCN5 mutation. Other criterion was the agreement to be subjected to blood and urine sampling for genetic analysis.

The higher percentage of idiopathic hypercalciuria - 52\% - than previously described (Rebelo et al. 1996), is in part due to selection criterion. As it is known, absorptive hypercalciuria type II patient on low calcium diet can reduce urinary calcium excretion to normal range and, in this study, the diet calcium content was not taken into account. This was the reason to include "normal" calciuric idiopathic nephrolithiasis with or without nephrocalcinosis in the search for CLCN5 mutation disease, generally described as a hypercalciuric disease.

Although clinical features of CLCN5 mutation diseases manifest mainly in affected man, female nephrolithiasis and/or nephrocalcinosis have been reported but normally the carrier woman is not symptomatic (Scheinman 1998, Reed et al. 2002).

Based on aforementioned clinical features, the patients were involved in a CLCN5 gene study, whose mutations led to a rare condition that could be misinterpreted as idiopathic nephrolithiasis and nephrocalcinosis, since the affected patients can manifest any feature of metabolic disarrangements seen in idiopathic nephrolithiasis. However, con- 
trasting to idiopathic lithiasis, in men, not in women, chloride channel disease has a worse prognostic caused by progressive renal failure culminating to end stage renal failure in a young age.

None of our patients had CLCN5 gene mutation, supporting the well known idea that most of calcium stone formers and nephrocalcinosis patients are not fenotypes of the chloride channel disease named Dent's disease or X-linked calcium nephrolithiasis (Scheinman et al. 2000).

\section{ACKNOWLEDGMENTS}

The present work was supported by grants from NIH (HL 47122 and DK 32753), Fundação José Bonifácio (FUJB), Fundação Carlos Chagas Filho de Amparo à Pesquisa do Estado do Rio de Janeiro (FAPERJ), Fundação de Amparo à Pesquisa do Estado de São Paulo (FAPESP) and Conselho Nacional de Desenvolvimento Científico e Tecnológico (CNPQ).

\section{RESUMO}

Trinta e cinco pacientes ( 23 homens e 12 mulheres) com idade de $35 \pm 13$ anos apresentando nefrolitíase idiopática cálcica, nefrocalcinose ou insuficiência renal leve com nefrolitíase idiopática cálcica foram selecionados para análise de proteinúria de baixo peso molecular e a ocorrência de possíveis mutações no gene CLCN5. A razão entre a $\beta 2$-microglobulina urinária e a creatinina urinária $(\beta 2 \mathrm{M} / \mathrm{Cr})$ foi muito elevada em uma mulher transplantada com nefrocalcinose $(>3.23 \mathrm{mg} / \mathrm{mmol})$ e levemente elevada em cinco pacientes ( $>0.052 \mathrm{ou}<1.0 \mathrm{mg} / \mathrm{mmol}$ ) com manipulação urológica múltipla. Outros pacientes estudados mostraram uma razão $\beta 2 \mathrm{M} / \mathrm{Cr}$ nos limites normais (0.003-0.052 mg/mmol) sem diferença entre os sexos ( $p$ > 0.05). A análise da mutação do gene do gene CLCN5 foi realizada em 26 pacientes dos 35 selecionados (11 com hipercalciúria idiopática; 6 homens com calciúria normal; 3 com leve insuficiência renal e 6 com nefrocalcinose) e não apresentou alteração em nenhum dos casos, mesmo naqueles com proteinúria de baixo peso molecular anormal. Conclusão: A mutação do gene do CLCN5 não é uma causa comum de calculose renal ou nefrocalcinose no grupo de pacientes brasileiros estudados.

Palavras-chave: nefrolitíase, nefrocalcinose, proteinúria de baixo peso molecular, mutação do CLCN5.

\section{REFERENCES}

Danpure CJ, Pardue Pe, Fryer P, Griffiths S, Allsop J, Lumb MJ, Guttridge KM, Jennings PR, Scheinman JI AND Mauer SM. 1993. Enzimological and mutational analysis of a complex primary hyperoxaluria type I phenotype involving alanine: glyoxylate aminotransferase peroxisometo-mitochondrion mistargeting and intraperoxysomal aggregation. Am J Hum Genet 53: 417-432.

Frymoyer PA, Scheinman SJ, Dunham PB, Jones DB, Hueber P and Schroeder ET. 1991. X-linked recessive nephrolithiasis with renal failure. $\mathrm{N}$ Eng $\mathbf{J}$ Med 325: 681-686.

Hoopes RR JR, Hueber PA, ReId RJ JR, BrADEN GL, Goodyer PR, Melnyk AR, Midgley JP, Moel DI, Neu AM, VAnWhy SK et AL. 1998. CLCN5 chloride-channel mutations in six new North American families with X-linked nephrolithiasis. Kidney Int 54: 698-705.

Igarashi T, Hayskawa H, Shiraga H, Kawato H, YaN K, Kawaguchi H, Yamanaka T, Tsuchida S And AKAGI K. 1995. Hypercalciuria and nephrocalcinosis in patients with idiopathic low-molecular-weight proteinuria in Japan: Is the disease identical to Dent's disease in United Kingdom? Nephron 69: 242-247.

Miller DG, Tiwari R, Pathak S, Hopwood VL, GilBERT F AND HsU TC. 1998. DNA repair and mutagen sensitivity in patients with triple primary cancers. Cancer Epidemiol Biomarkers Prev 7: 321-327.

Rebelo MAP, Leite JAG and Araújo NC. 1996. Hipocitratúria na nefrolitíase cálcica. Incidência e morbidade. J Bras Nefrol 18: 21-27.

Reed BY, Gitomer WL, Heller HJ, Hsu MC, Lemke M, PAdAlino P AND PAK CY. 2002. Identification and characterization of a gene with base substitutions associated with the absorptive hypercalciuria phenotype and low spinal bone density. J Clin Endocrinol Metab 87: 1476-1485.

Scheinman SJ. 1998. X-linked hypercalciuric nephrolithiasis: Clinical syndromes and chloride channel mutations. Kidney Int 53: 3-17.

Scheinman SJ, Pook MA, Wooding C, Pang JT, Frymoyer PA ANd Thakker RV. 1993. Mapping the gene causing $\mathrm{X}$-linked recessive nephrolithiasis to Xp11.22 by linkage studies. J Clin Invest 91: 2351-2357. 
Scheinman SJ, Cox JPD, Lloyd S, Pearce SH, SALENGer PV, HoOpes RR, Bushinsky DA, Wrong O, Asplin JR, LAngman CB ET AL. 2000. Isolated hypercalciuria with mutation in CLCN5: Relevance to idiopathic hypercalciuria. Kidney Int 57: 232-239.

Stoller ML, Bruce Je, Bruce CA, Foroud T, Kirkwood SC and Stambrook PJ. 1999. Linkage of type II and type III cystinuria to $19 q 13.1$ : codominant inheritance of two cystinuric alleles at 19q13.1 produces an extreme stone-forming phenotype. Am J Med Genet 10: 134-139.
Wrong OM, Norden AGW AND FeEst TG. 1994. Dent's disease: A familial proximal renal tubular syndrome with low-molecular-weight proteinuria, hypercalciuria, nephrocalcinosis, metabolic bone disease, progressive renal failure and a marked male predominance. Q J Med 87: 473-493. 